\title{
'Organizational-Social-Capital, Time and International Family SMEs: An Empirical Study from the East of England'
}

Abstract. Previous studies on family-SME internationalization have largely focused on what resources are needed to drive an incremental process rather than how resource management occurs in historical time. This paper focuses on the latter, adopting a social capital perspective (capturing both internal, i.e. among family-SME board members, and external, cross border agent dyads, relations) in order to decipher case study data from the East of England. Findings show that it is not the presence or absence of organizational-social-capital that affects family-SME internationalization success but rather its variable use over the years driven by the future pursuit of longevity, not growth. Key within this context is the variable use of the international expertise and management capability of non-family managers in the family SME intra-organizational context. Ultimately this may lead to change and learning that occurs erratically, often including reversals, without causing family-SME progression across a sequence of incremental stages.

Keywords: family business; internationalization; social capital; history; SME.

\section{Introduction}

The growing integration of firms of all sizes, and particularly SMEs (Small and Mediumsized Enterprises) in international and global networks of production and distribution is now widely acknowledged as important for long-term growth. This underpinned the emergence of a growing number of studies examining the internationalization of the SME (Jones, Coviello and Tang, 2011; Zahra, Ucbasaran and Newey, 2009). This body of knowledge builds on the conceptual premise that 'size matters'. The impact of smallness is invariably viewed in terms 
of resource-related constraints, as well as the over-arching influence of the entrepreneurial personality (Kalantaridis, 2004). Within this context, the literature focuses heavily on a handful of key research questions: which national markets shall an SME enter, how (mode of entry), and when (in relation to the stage in the development of the firm), as well as the impact of internationalization on business performance. A dynamic perspective (introducing sequential time) and resource availability are central planks of the emerging body of knowledge in SME internationalization, and cut across diverse theoretical constructs.

More recently, and within this intellectual context, a new stream of research has emerged: focusing on the internationalization of family SMEs (Arregle et al. 2012; Fernández and Nieto, 2005). The distinctiveness of this (process), in comparison to SME internationalization more widely, is underpinned by the defining attributes of family businesses (Fernández and Nieto, 2005; 2006; Kontinen and Ojala, 2010) (providing the rationale for this paper) and reflects the numerical significance of family SMEs. The importance of family SMEs is unquestionable, provided that they represent up to $85 \%$ of all the firms in the EU and USA (Kontinen and Ojala, 2012).

Existing research on family SMEs identifies three reasons why the internationalization process in this empirical context may differ from that of SMEs in general. Firstly, the emphasis placed by members of the owning family upon the survival of the firm in the longterm, rather than profits realised in the short to medium-term, influences the propensity to take risks, often associated with internationalization (Fernández and Nieto, 2005; Zahra, 2003). Secondly, internationalization success is viewed as inherently conflictual (between owners and specialist managers) and is attainable only when balance is achieved between two desirable but incompatible managerial features (stewardship and ambassadorship) or in other words an organizational bargain (Arregle et al., 2012; Sciascia et al., 2013; Pukall and Calabrò, 2014). Lastly, the strong internal ties of family SMEs are likely to influence 
adversely their ability to form networks with other businesses (Graves and Thomas, 2008; Kontinen and Ojala, 2011a; 2011b). This, in turn may restrict their ability to tap into sources of information needed in order to identify and exploit international opportunities. The emerging body of literature has focused squarely on export sales (Zahra, 2003; Fernández and Nieto, 2005; Kotey, 2005; Sciascia et al., 2013) or people's strategic aspirations (Gallo and Garcia-Pont, 1996; Graves and Thomas, 2008; Kontinen and Ojala, 2011a; Yu, 2001) rather than on resource management over time (Pukall and Calabrò, 2014: 112). This led Kontinen and Ojala (2010: 106) to argue that "there is limited knowledge on the processes and strategies that make family businesses unique in their internationalization”.

In response, we set out to decipher: how internationalization processes, focusing particularly on resource management, are shapped by the defining attributes of family businesses (i.e. the pursuit of longevity, conflicting interests between owners and specialist managers, and an internal ties emphasis)? This is fundemantally a study of the imprint of the distinct family business organizational form on SME internationalization. In doing so, we explore not only 'becoming' international but also remaining and even retreating from internationalization, thus adopting a focus that extends to post-entry outcomes (Reuber, 2016). In order to achieve our research objectives, we introduce two conceptual advances in the family SME internationalization literature.

Firstly, we adopt a social capital perspective that is increasingly influential in family business research (Arregle et al., 2007; Pearson et al., 2008; Carr et al., 2011). Payne et al.'s (2011: 491) definition of social capital as "the resources derived from social relationships" is adopted here, thus following an approach that embraces its theoretical "potential as a multilevel lens". However, unlike previous family business research (Pearson et al., 2008; Carr et al., 2011), we avoid limiting our gaze to interaction within the family organization (Adler and Kwon, 2002) or Quadrant 2 in Payne et al.'s typology, but also include what is 
happening outside the boundaries of the firm. Such an approach assists our efforts to reconsider the value-adding potential of non-family managers, in the case of our paper often involved in export activity, whose exclusion from past research was lamented by SanchezFamos et al. (2015): thus, adding another level of analysis to social capital and examining it qualitatively in the family SME context. This also provides a useful link with the concept of negative social capital: that is empirically unpicked when it remains internally (i.e. among SME family board members) focused.

Moreover, this perspective facilitates the advancement of a conceptual distinction between sequential time, with an inherently incrementalist logic, that dominates the existing body of literature on SME internationalization, and historical time: the second conceptual advance of the paper. In contrast to the existing literature where emphasis is placed on learning that underpins a move from one stage to another (sequential time), we believe that the enduring involvement of the family, and the emphasis that it places on SME longevity, serves as a unique historical condition that influences internationalization (Pearson et al. 2008). In this context, historical time, in what may be an intermittent and not incremental (but undoubtedly accumulative) process, emerges as a key consideration.

The paper is organised as follows: the relevant body of literature and the key concepts used in our paper are presented in the next Section. Then we proceed to discuss the study's research methods used to collect and decipher the primary data. Empirical material is presented in the fourth Section of our paper, followed by discussion. Finally, conclusions of the main findings are drawn with respect to the genesis of such organizational-social-capital.

\section{Literature Review}

\subsection{SME Internationalization}


The effects of smallness (captured invariably in terms of employment) led to the emergence of a broad and diverse body of literature on SME internationalization. Whilst reviewing this body of work goes well beyond the confines of our paper, a brief overview of internationalization dynamics and resource availability, that influenced family SME internationalization research, constitutes the point of departure of discussions around time considerations (and the divide between sequential and historical) and social capital.

In large chunks of the literature, SME internationalization is viewed as a sequence of stages defined by (organizational) experimental learning that increases (market) knowledge and leads the SME to increased (market) commitment (Ruzzier et al., 2006). In the Uppsala model this is manifested in terms of the SME either entering new, less distant (not only geographically but also psychologically/culturally) markets or adopting different modes of entry with increasing levels of international commitment (Johanson and Vahlne, 1977). This is the case even when 'distance' has been revised in this model by putting network specificity and the liability of outsidership in the place of country specificity and the liability of foreignness (Johanson and Vahlne, 2009). Alternatively, individual learning and the role of top managers lie at the core of progression from a pre-export stage to advanced export stage articulated in innovation models (Cavusgil, 1980). Similarly, network approaches to internationalization focus on gradual learning and the accumulation of market knowledge through interaction within networks (Johanson and Mattson, 1993; Debrulle and Maes, 2015). Within this intellectual context, resources also occupy a central place. Ahokangas (1998) assumes that SME internationalization is conditional on the presence of key internal and external resources. These may be developed within the SME and between the SME and its environments. This is analysed along two dimensions: firstly, where do the resources reside; i.e. what is their source - are they internal or external to the SME; and secondly, does the 
development of resources take place in a firm oriented manner (inward orientation) or in a network oriented manner (outward orientation)?

\subsection{Family SME internationalization}

The defining characteristics of family firms underpinned the emergence of a new stream of work within SME internationalization. Thus, it is not only smallness that matters (often captured in terms of employment as entities engaging less than 250 persons), but also the defining influence of the owner's family dynamics and business self-perception on managerial behaviour (Howorth et al., 2010). Pertinent implications of this, identified in the Introductory Section, include the pursuit of longevity, conflicting interests between owners and specialist managers, and an internal ties' emphasis.

One manifestation of the pursuit of longevity is the taking for granted reluctance of family SMEs to internationalize (Gallo and Garcia-Pont, 1996; Kotey, 2005; Kontinen and Ojala, 2010; Scholes et al., 2016). The risk avoidance attitudes of these firms may be mitigated by the adoption of an incremental international approach as advanced by the Uppsala model (Pukall and Calabrò, 2014). At the same time however, family firm ownermanagers (pursuing longevity) were seen to act as good stewards of the firm's resources (Pukall and Calabrò, 2014). The longevity pursuit of family businesses (as reflected in succession) affects board composition and positively associates with a propensity to export provided that second-generation proprietors are likely to introduce new ideas and push harder towards growth (Kotey, 2005). Adding further detail into these insights, more recent research suggests that the effect of succession on the commitment to internationalization is not unidirectional but can be heavily dependent on the successor's vision and thus positive or negative (Graves and Thomas, 2008). International orientation is seen in this literature as the successor's personal goal and managerial capability/characteristic that escapes, or not, the 
family firm's high degree of behavioural integration (bonding). By contrast, there is a dearth of studies examining the international management processes employed by family firms and how their bridging social capital works intra-organizationally (Kontinen and Ojala, 2010).

The conflicting interests of owners and specialist managers lie behind Zahra's (2003: 510) conclusions that "family ownership enhances managers' psychological ownership, probably reducing managers' perceptions of the risks associated with internationalization". Pukall and Calabrò (2014) similarly identify the potential beneficial effects of moderate levels of family ownership that embraces the external influences of specialist non-family managers in the board of directors. Fernández and Nieto $(2005 ; 2006)$ also argue that Spanish family SMEs that have large-block shareholding ties with other companies and become less familyowned appear to enjoy increases in their export propensity/intensity. This is in line with Sciascia and Mazzola's work (2008) on Italian family SMEs' performance that testifies to the more beneficial effect of opening up their management team rather than equity capital to nonfamily members (i.e. having a diverse board composition). Managing in international firms requires high quality (Gallo and Sveen, 1991). Negative accounts of family members leading overseas operations are reaffirmed in Chinese family businesses (Tsang, 2002). The adverse effects of distrusting outsiders and trying to preserve family harmony on internationalization are encountered in Singaporean small family firms even by scholars who attempt to incorporate the socioemotional wealth concept (as an affect-related value adding theoretical lens of family business behaviour) into the revised Uppsala model (Scholes et al., 2016).

Within the context of the internal ties emphasis of family SMEs there is considerable (or even excessive) emphasis placed on family-social-capital and its resource specificities (Sanchez-Famos et al., 2015). Stability, interaction, interdependence and closure typically characterise family relationships in the business (Arregle et al., 2007; Pearson et al., 2008). As Kontinen and Ojala (2011: 451) however, point out "among family SMEs, international 
opportunity recognition does not commonly take place through existing networks ties". To this extent, an attempt is made here to overcome the excessive focus placed by the resourcebased view on the exploitation of existing firm-specific assets (Chirico and Salvato, 2008) and examine the contributions of what lies outside the family firm's current resource base as deployed in its 'mainstream' operations. This allows consideration of internationalization as a diversification activity, driven either by the pursuit of new or in response to diminishing (domestic) opportunities, that stretches beyond the single firm (and its formally planned strategies) and considers the implications of changing external and internal circumstances (Rosa et al., 2014).

\subsection{Sequential and Historical Time}

Firm internationalization research, regardless of size or distinction, ignored time issues or used sequential time in its conceptualization and thus developed incremental models of internationalization. Such research has largely focused on the "consequences of a change in the degree or nature of a firm's international involvement" (Liesch et al., 2002: 27). As Abbott's (1995) succinct understanding of sequence in social science though points out, linear stage theories, though widespread, do not account for contingency and accident. Instead the ordinal representation of time as a linear succession of instants is dominant in incremental models that ignore the weight of the future and embrace an episodic dimension (Ricoeur, 1980). Such an objective clock-based representation (e.g. measured invariantly with age, duration or lifecycle variables) leads "to a cultural homogenization of time" and "assumes that past trends are replicated into the future" (Sharma et al., 2014: 11; 14). By contrast, in a historical order of things "reality occurs not as time-bounded snapshots within which 'causes' affect one another, but as stories, cascades of events" (Abbott, 1991: 227). In other words a historicality that configurationally (rather than episodically) "construes significant wholes out 
of scattered events" taking into account the subjective role of both (past) memory and (future) expectation (Ricoeur, 1980: 178).

Informed by this sociological literature on temporal dimensions, time is viewed here in two different ways: sequential time in which social events and actions episodically intertwine (irreversible but dynamic) and historical time in which social events and actions configurationally reoccur (discontinuous but coherent). In short, sequential time represents a continuum - even when it is conceptualised subjectively (Ancona et al., 2001; Sharma et al., 2014), whereas historical time mirrors a non-progressive repetition (Munn, 1992). Thus this study relies on a historical conceptualization of time, whilst both owner-managers and nonfamily managers and their conflicting goals are seen to be as much socialized as selfinterested and anchored, though their experiences, within a present that engages both past and future horizons (Munn, 1992). Historical time accounts here for what cross-border agent interaction is repeated over the years and across companies, whilst sequential time depicts the stages of cross-border family business interaction in a linear manner. In this setting, nonfamily managers are seen to bring in the internationalization process their cross-border histories and lived time experiences before joining the family business and hence their temporal vista is often different from those of family members (Sharma et al., 2014).

\subsection{Organizational-Social-Capital}

There is increasing acknowledgement that "the family is a source, builder of social capital" (Bubolz, 2001: 130), and that relationships among family members present a breeding ground of social capital (Coleman, 1988). This, in turn, underpinned growing interest on the centrality of family-social-capital and how it affects organizational-socialcapital (Arregle et al., 2007). Research within this context attached primacy (implicitly) on family-social-capital viewing the increased role of non-family stakeholders in organizational- 
social-capital development as undermining social capital generated within the family (Arregle et al., 2007).

However, there is recognition in the literature that there is also 'negative' social capital that is particularly relevant in the context of internal relations among family SME members. This focuses on how various kinds of networks have a clearly exclusive function (Westlund and Bolton, 2003). Moreover, the prevalence of common norms may create conformity, which, in turn, may impose restrictions on both individual freedom and business innovation (Portes and Landolt, 1996). Portes (1998: 15) went on to identify four negative consequences of social capital: "exclusion of outsiders, excess claims on group members, restrictions on individual freedoms, and downward levelling norms". In family firms, this underlines the importance of non-family social capital that can provide access to extended networks (a key consideration in the internationalization process) and facilitate interaction with diverse external stakeholders (Ng and Roberts, 2007).

This study, unlike the bulk of past research, departs from the concept of organizational-social-capital that is defined as "a resource reflecting the character of social relations within the organization" (Leana and Van Buren, 1999: 538). There are two basic components of this organizational-social-capital. The first comprises of "trust in terms of a risk-reward relationship" (Leana and Van Buren, 1999: 543). Trust in this context is linked with a specific history of international interactions (at an individual level), and can only exist in a conceptual framework where historical time is present. The second component focuses on "mutual identification" (at a collective level) that represents a "perception of oneness" (Ashforth and Mael, 1989), works through the group's operation as a reference group (Nahapiet and Ghoshal, 1998) and emerges from a cognitive process of self-stereotyping (Millward and Postmes, 2010). Mutual identification can also be overdeveloped (e.g. through 
a non-diverse SME board composition), even becoming an impediment to innovation (Arregle et al., 2007) or an instrument of free-riding (Portes, 1998) and ossification (Uzzi, 1997).

Such organizational-social-capital draws its origins and strength from both internal (among family SME board members) and external relations (cross-border agent dyads) that are not seen as separate spheres of influence but rather as being integrated and simultaneous. As Adler and Kwon also advocate (2002: 35), "external ties at a given level of analysis become internal ties at the higher levels of analysis, and, conversely, internal ties become external at the lower levels". Organizational-social-capital as viewed in our international family SME case study work is captured schematically in Figure 1 (the conceptual framework) that includes in its cross-border trust component the history of social interactions and network overlaps brought to the firm by both family and non-family members. In such a conceptualization, we overcome Arregle et al. model's (2007) limited focus on how only family connections create, lead to and occasionally dominate organizational-social-capital and show certain conditions in which the latter flourishes by growing independently of familysocial-capital. In this manner, the heterogeneity of the family firm's internal groups (Arregle et al., 2007) is historically combined with the homogeneity of their members' external ties in the development of organizational-social-capital. We put forward that both family and nonfamily members have their 'own' history of individual relationships (personal biography) and at the same time face the challenge of collective board decision-making and role specificity (mutual identification component in Figure 1) that greatly influence family SME internationalization. To get inside the world of those managing the family SME internationalization process and generating such organizational-social-capital, there is a need to employ a qualitative approach as this is particularly well-suited in order to develop theory answering the 'how' questions and offering an integrated consideration of context (Reay and Zhang, 2014). 
In this conceptual framework, successful international trade is more often than not a symbiosis of outward-facing internationalization management and inward-facing family SME ownership and control, where efficiency goals meet with the quest for new export markets and organizational performance (Arregle et al., 2012; Sciascia et al., 2013). The focus rests on 'arrows' rather than 'boxes' and the true nature of the relationship between the conceptual framework's components (Gilgor et al., 2016). More specifically, the family SME owner's cognitional success in detecting and responding to overseas consumer demands is viewed here as being unsustainable. This is because the former has to be not only willing to undertake an internationalization strategy but also be able to internally neutralize the overall managerial weight of it by appointing a so-called 'ambassador to internationalization' that is often a nonfamily manager/director. A centralized appraisal system which adequately rewards nonfamily managers for building cross-border agent trust, albeit without incorporating them into a levelled organizational structure and its blind spots of mutual identification, is a source of valuable organizational-social-capital. Timely coordination between production and sales is the particular task attributed to the non-family manager who normally devotes more effort to operational rather than strategic goals. We suggest that the practice of conferring shares to non-family export managers/directors who succeed in leading the family enterprise to prosperity but also that of retaining a certain asymmetrical growth in shareholding that aims to maintain majority ownership lies at the heart of international family SME success stories.

But are such ambassadors to internationalization just a luxury for family SMEs? Kalantaridis' results (2004) have already suggested that overall there is little disparity in strategy development among internationalized enterprises of different sizes located in England. Reluctance to internationalize is not necessarily a reflection of size even for those 
who study family multinationals (Lubinski et al., 2013). Alternatively, network relationships are increasingly seen as being able to overcome size constraints in the SME internationalization literature (Debrulle and Maes, 2015). A different case in point is Coviello and Munro's study of international market growth for entrepreneurial high-technology firms in New Zealand (1995), which demonstrates that the selection of foreign markets modes of entry emanate from opportunities created through (formal/informal) network contacts rather than solely from managers' strategic decisions. Harris and Wheeler's Scottish SME qualitative research (2005) has also questioned the wisdom of engaging directly in foreign markets for owner-managers. Interestingly, it appears here that similar non-strategic export initiatives are encountered by English family SMEs, relationally drifting into their boardrooms from without, whose contribution is to diversify the customer base over time and control the curvilinear effect of the share of foreign sales (Hassel et al., 2003). We argue that these processes are underpinned by organizational-social-capital.

\section{Data Collection Methods \& Analysis}

\subsection{Data Collection}

This paper adopts a comparative case study approach because its aim is not to spot or construct a gap in the internationalization literature, but rather to (qualitatively) problematize the assumption of dynamism (sequential time) (Alvesson and Sandberg, 2011). Our case study data collection was situated from the start "within the larger conversation in the field" that allowed us to "make the local globally significant" (Chenail, 2009: 105), counterbalance the quantitative empiricism dominating international business research (Doz, 2011), use a blended (inductive and deductive) analytical approach and thus to debunk the myth of employing qualitative data as a means of building rather than of complementing and illustrating theory (Graebner et al., 2012). In this manner, we were able to develop 
"theoretical findings that can stand on their own" (Doz, 2011: 586), confront theory with the experienced world and seek the critical realist's causes-of-effects explanation (Welch et al., 2011) - thus identifying the 'time and context-bound' past use of resources in international family SMEs rather than predicting its future impact. We thus opted for a pluralistic perspective that aims to explain phenomena by looking backwards and by understanding the reasons behind decisions, albeit without refusing to engage with 'paradigmatic interplay' that we believe greatly facilitates theorizing and assumption awareness (Shepherd and Challenger, 2013; Leppäaho et al., 2016). As a result, replication and proposition-building were not condemned by default as belonging to positivism and therefore excluded as irrelevant to our qualitative research endeavour.

A total of thirteen cases with "a deep and insightful understanding of collective action in context" (Doz, 2011: 585), are included (containing one family firm that discontinued exporting and one that did not follow it through). The cases were selected from a population of 1,131 enterprises (included in a quantitative SME telephone survey representative of the East of England region by broad industry sector). Cases were purposefully selected to capture diversity in context in terms of sector, size, age and geography within the East of England as shown in Table 1. SME case selection was accomplished on the basis of interviewee availability and proximity to our institution (thus excluding East Anglia). The cases were also defined as family SMEs (or not) on the grounds of two criteria measures (used in the UK context even when private family firm heterogeneity is examined - see Westhead and Howorth, 2007): majority family share ownership/control and self-identification. A key decision towards mitigating bias in data collection was to interview organizational actors located in various hierarchical positions who viewed family SME internationalization from diverse perspectives: owners, owner-managers, export managers and other directors. 
The thirteen family SMEs examined in our paper are all engaged in manufacturing activities, in order to provide comparability of context in internationalization activities. This is because the scope and nature of internationalization varies considerably in service industries (for example in hotels and restaurants). We have also tried to include enterprises of different sizes, from micro to medium-sized (Table 1). The family SMEs under investigation demonstrate considerable differences in the number of generations involved in the business: just over-half being first generation, around $40 \%$ second, and one being fourth generation. They also appear to involve diverse models of engagement with international markets: including exports (all of the SMEs) both direct (four) and indirect through agents etc. (the remaining), imports (around half), and production (around a sixth). In this background, their distinct family SME internationalization trajectories at work are identified below using the notion of organizational-social-capital as the primary line of logic.

\section{INSERT TABLE 1}

The interviewees were invited to talk about their internationalization experiences through time and tell us why they internationalized the way they did. Beyond the processes at work key themes discussed included: the background of the key decision-maker(s) and implications for the processes at work, motivations, and characteristics of the enterprise (focusing particularly on ownership patterns) and their change. Problems confronting internationalization processes and contextualized ways (and means deployed) to overcome these were also raised with interviewees. Our interviewing techniques included event tracking alongside 'back-in-time' and nondirective questioning of knowledgeable and anonymous actors that yielded "information convergent among informants and with archival data", improved both interviewee candour and memory accuracy, and therefore gave us increased confidence that the dangers of interview bias were significantly reduced (Bingham and Davis, 2012: 615). 
Verbatim transcription accompanied the summary case reports of key points that were generated immediately after each business history interview and with the help of company documents supplied or found online at that time. This enhanced the analytical space for recognizing emergent patterns of historical time in family SME international activity later on. At that stage, it was accepted that "less will be reported than was learned", whilst the summary case report itself reflected "the observation of operations" (Stake, 1994: 240, 242). Interestingly, the lack of focus on family firms per se at the time of the interview and summary case reporting helped to increase validity by avoiding interviewee and interviewer bias in the way the data was both collected and interpreted. Within each case a 'whole study' analysis was thus compiled and only subsequently, each case's conclusions about the 'journey' of their family SME internationalization were "considered to be the information needing replication by other individual cases" (Yin, 2009: 56). To this extent, cross-case synthesis was only performed afterwards to show the unique context of international family SME lives across time and space and thereby "shed light into differences between seemingly similar cases and similarities between different cases" (Brannen and Nilsen, 2011: 615). We made no attempts to select a theoretical perspective before the data analysis started but rather engaged with the literature in a back-and-forth manner as empirical categories emerged.

\subsection{Data Analysis}

Existing research on SME internationalization has commonly used typologies for the purposes of summarizing diverse empirical processes. For example, based on qualitative small business research undertaken in North-East England, Atherton and Sear (1998) outline the stages of new market development process according to levels of expertise in managing it ranging in potential from inexperienced through experienced and to (internationalized) expert. In a similar fashion, Julien et al.'s work in Canada (1997) distinguishes professional exporters 
from opportunistic exporters on the basis of their level of SME success in acquiring export objectives, whilst Piercy (1981) differentiates between active and reactive medium-sized exporters in northern England. However, by using owner-manager types and firm-level strategies as explanations for family firm export success - an approach that can be associated with the Uppsala model (Johanson and Vahlne, 1977; 2009) - one neglects the organizational factors which can help to bypass the structural, relational and cognitive impediments to internationalization. To this extent, erratic internationalization patterns have rarely been accounted for and exporting is hardly seen as a discontinuous process (that is grows, declines and re-grows) in intra-organizational terms. Nevertheless, multiple-case rationales and typology work still remain the best way of capturing the heterogeneous nature of internationalization provided that such methodologies allow a "progressive focusing" on the various conditions underlying the discrimination they make (Hammersley and Atkinson, 1983). Following Aaboen et al.'s insight (2012: 245), the comparison among our retrospective (multiple) family SME cases focused "on patterns in the processes of learning and interaction" and paid attention to "series of events rather than to snapshots of moments in the development" of cross-border activities.

As Yin (2009: 59) also highlights, "multiple-case rationales can derive from the prior hypothesizing of different types of conditions and the desire to have subgroups of cases covering each type". In this study, cross-border trust in terms of risk-reward relationship and the family-SME board composition were the two (literature drawn) dimensions used in order to decipher organizational-social-capital in each case's journey of family SME internationalization (Figure 1 and 2 - see below in italics the first-order categories used in our open coding). The former was operationalized in terms of a history of international interactions either by the owning family or non-family managers. The latter was theoretically encapsulated as mutual identification and operationalized in terms of inward or outward 
orientation that is a family SME board composition (and its various shareholding stakes) driven by the pursuit of longevity or growth respectively. At first, open coding was employed to manually highlight and sort concrete interview data regarding these two dimensions. Sentences or paragraphs constituted our coding units. Related parts of the verbatim transcripts were compared and contrasted with the firm-centred SME internationalization theoretical constructs reviewed in Sections 2.1 and 2.2, retaining a sense of context (time or space), whilst negative examples (e.g. failed internationalization) were embraced as routes to expand understanding. This method complies with Yin's authoritative suggestion that (2009: 35) “for case studies, theory development as part of the design phase is essential ... a point of difference".

Secondly, cross-case comparisons were made by coding interviewee's verbatim statements leading to the emergence of the following three decision-making factors behind family SME internationalization: 'control', 'finance' and 'market' (in italics are the secondorder categories used in our axial coding). "Systematic comparison across units of data" involved asking "what is this sentence about?" or "how is this text different from the preceding text?" and cutting and sorting techniques of marked text (Ryan and Bernard, 2003: 91). Identification of processes around these three additional factors further informed our understanding of the two initial dimensions (driven by the literature) as underpinning family SME internationalization attempts and adaptive moves and thereby led to a subgrouping of cases into four positions (opportunistic, reluctant, leading and failed internationalization) in the 'third pass' through the interview data (in italics are the core categories used in our coding). Here we sought to shed light on the intra-organizational conditions that led to these four positions (international family SMEs with high or low levels of cross-border trust and inward or outward facing board composition) and it is at this point that we mapped such conditions (and their varying types of market, control and finance) onto the aggregate 
theoretical dimension of historical time through selective coding (Figure 1 and 2). The use of the term position is preferred over the inherently incrementalist 'stages'. Each position is embedded in historical specificity, which in turn creates path dependence and can be managed through the variable formation and use of organizational-social-capital. The analytical approach thus adopted in this case study work was "tightly linked to data" and involved "constant iteration backward and forward between steps" (Eisenhardt, 1989: 532, 546).

INSERT FIGURE 2

\section{Findings}

\subsection{Opportunistic Internationalization: The overseas chance of increasing turnover}

This group of family SMEs is defined by the opportunistic manner in which it approaches internationalization (i.e. exporting and at times importing): invariably in pursuit of increased turnover and as a result of saturation of their domestic market (in a manner of pull diversification as identified by Rosa et al. (2014)). These are mostly mature firms, with large capital investment aimed at long-term profitability in their core home market, but alert to (particularly) export opportunities as a means of producing gains (see Table 1). As Harry, a board member and since 1983 the Managing Director of a manufacturing company of professional food cutting work-surfaces (16 employees, $10 \%$ imports, $20 \%$ exports) explains: "In the early 1980s, we were nearly all UK market only and at that particular point we really wanted to grow bigger and there was no more left in the UK for us". In this framework, being passive and not catering for customers' expanded needs overseas involves greater risks, whilst export opportunities can secure critical additional resources.

In other instances, exporting materializes as a necessary push out of domestic trading due to unfavourable conditions as the example of a specialised manufacturer of elevators and conveyors demonstrates. In this case, a brand new export manager used his expertise and 
"(personal) contacts (abroad)" to pull the family firm out of its financial troubles: "In 1988, we appointed an export manager who stayed here for 10 years. We were discounting the maximum in order to get the business abroad. Exports rose to $10 \%$. We've got to keep the factory busy otherwise our costs go sky high. They saw exporting as a way of increasing the turnover" (Nick, 120 employees). As rapid expansion is rarely welcomed in family firms (especially in relation to the number of countries entered, see Zahra, 2003: 507), precautions were often taken in regard to the related operating costs. Jim (20 employees, $8 \%$ imports, $1 \%$ exports), a sales manager who works in a family firm manufacturing power supplies for use in electronic security systems emphatically reminds us: "the more products we sell the more we have to wait for the payment". In this opportunistic trajectory, a family SME exporter can even enjoy phenomenal periods of international sales when a 'deep niche' need for an innovative product is satisfied in the short-term. Helen's account (publisher, 7 employees) is illuminating: "We (personally) relate (with our foreign distributors) ... When we brought the product out in 1992 this firm followed suit and they now flood the market with those books ... for such a cheap price ... Our turnover was halved and 8 people lost their jobs in 1998". The international managerial control is thus personalised: "if we're going to export to a country I like to see, feel and touch it first ... I don't like (communications) to be faceless" (Harry, 16 employees).

\subsection{Reluctant Internationalization: The overseas deterrent of facing unhealthy balance sheets}

Another group of family SMEs claimed reluctance to internationalize on account of concerns about the implications of engaging in relatively risky operations across borders on balance sheets. Among those husband and wife (Lucy, 5 employees) stated: "I mean we do export obviously (3\%) but only as and when the customer-driven opportunity (gradually) arises but it's not our policy to look for export orders". Controlling the export challenge rather 
than balancing its risk with other relational concerns and resource combinations across organizational boundaries is the guiding principle of such family SME management. Internationalization is perceived here as a continuous process that endures rather than a particular one that reoccurs over historical time.

The lack of overdraft facilities is eulogized by those reluctant exporters who followed the traditional family business model of unquestioned mutual identification which dictated aversion to credit, survivalism and maximum profit returns on a given and non-fluctuating turnover. Little is wasted on consumption with the majority of family business profits being reinvested in the firm, which is also a measure of the degree of inward business orientation and its effect on the firm's organizational-social-capital. This mostly leaves the family business balance sheet healthy, whilst any growth is gradual and financed internally with limited room for expansion: "the reason we don't take more people on is that we balance our business with the (overseas) outworkers or contractors ... have our product made over (cheaply) in the Far East (20\% imports, 5\% exports)" (Gareth, 13 employees). Export enquiries are reduced to the so-called "waiting for the phone to ring" for those who are domestic or 'made to order' market oriented, risk averse and "never went in for paying bonuses" (Alice, 19 employees). Risk-reward relationships as another important component of the family firm's organizational-social-capital are largely missing here.

\subsection{Leading Internationalization: The feat of co-developing overseas networks}

Leading internationalization is defined by a coherent and strategic approach to internationalization that involves a broad range of activities: exporting, importing and often international production. For example, Mark, now an export director of outdoor lighting equipment after 15 years of exporting service (160 employees, 25\% exports), aims to achieve 
the optimum profit margin with exporting not exceeding a quarter of the family firm's total turnover (that also includes 5\% imports from China), whilst the right mixture of products emerges as the firm's priority in planning its organizational-social-capital basis. "It's a question of getting the mixture right, it's also a neat balancing act within the factory" as family SMEs move through historical time (with international work often diminishing if the business shrinks but not necessarily disappearing). Horizontal foreign networks accomplished largely, but not exclusively, by the non-family managers are seen here to be instrumental in generating family SME export successes. It is also the case that such networks can exist independently of the family business itself, diversify the family firms' portfolio of financial interests and thus become another useful source of asymmetrical risk in its organizational structure e.g. "we have a factory near Beijing, a fairly big unit $\left(10,000 \mathrm{~m}^{2}\right.$, with 80 employees); it is a joint venture with Chinese partners". Only to the uncritical eye, however, does such social capital appear as the non-family member's individual asset. As is expressed in Mark's words (160 employees): “this business has been successful in building networks in foreign countries; a sales technique of being what's known as customer intimate, you try to make friends with them ... we obviously have a lot of training visits; the last one was from a customer in China, who placed an order with us and wished to come and inspect the fabrication and some of the equipment that we made here".

The cost advantage of scale thus cannot be realised within manufacturing family firms unless a balanced flow of exporting orders is maintained through the factory to assure effective capacity utilization. The example of James who spent the last 9 years working as an Export Sales Executive in a family business with international production facilities in USA that has more than 40 years manufacturing expertise in plastic technology ( 88 employees, $40 \%$ exports), is indicative. James describes his role as pivotal in building trust, intensive cooperation and long-term partnerships with the distributors, thus having to be trilingual and 
travel 7 working days per month. The export team offers ready-made knowledge and one-toone customer communication channels for the inward-facing family business ownership and a warped 'all family' board of directors (no external shareholders). In contrast to the redundant nature of international orientation for family SME owner-managers, cosmopolitanism remains an asset for non-family managers in that it gives them what James (88 employees) calls the "flexibility of mind to adapt the business to its customers' mentality". The (singular) nonfamily manager's function as an ambassador to foreign market networks arms him/her with immunity which results in freedom and exemption from mutual identification issues such as stewardship, family obligations and shareholder returns, offers shortcuts to improved export market information and an augmented networking ability to connect horizontally and build trust externally with corresponding level agents (both independent and other competing family business agents) on behalf of the family business. Such an ambassadorial role allows family SMEs to consolidate both components of their organizational-social-capital. Mark's case (25\% exports) typifies the leading family SME internationalization here whose aim is that of combining equal-sized firms and therefore declines openings offered by opportunistic circumstances: "My criteria for finding an agent are that s/he's got to match us roughly by size ... a smallish agent who's doing business on a personal basis and to whom we are about one third important".

Alternatively, Lee's export achievement is shown to be based on a horizontal networking success in a reverse mode which also led to the company's glorious transformation from a struggling manufacturer of fishing equipment to a successful distributor in the same industry in 1996 (95\% of its goods are imported from the Far East). The family SME owner has been a most respected angler in the industry and so his contacts within the fishing circles initially helped the company to sell goods to individual shops all over Europe (with its own warehouse in Belgium). In this case, the owner's hobby (fishing) represents the 
outward-facing element in the family business management in the sense that he has spent a disproportionate amount of time in building hobby-related networks rather than profit margins for the family business. Most importantly, the operational aspects of efficiently running this family business rest in the hands of a product development director and an innovative design team. Organizational-social-capital is achieved here the other way round but it once again leads to successful internationalization. In this context, it was soon understood that the distributors were not selling as much as they ought to and in 2000 the firm launched its own distribution network. Other efforts to penetrate the retail side by this UK market leader in the supply of specialised fishing equipment were voluntarily thwarted as a result of information once again feeding back from trust-driven networks that cannot be taken for granted: "buying online is not active at the moment ... we felt that it might upset some of the small retail shops" (Lee, 55 employees). Such 'hobbyist' family business owners thus take on the role that non-family export managers habitually assume and in this fashion they represent a fascinating example of how individual interaction at the micro-level (fishing) can create organizational performance ( $40 \%$ international fishing-equipment sales and almost doubling the turnover from $£ 6.5 \mathrm{M}$ to $£ 12 \mathrm{M}$ within a six-year period).

\subsection{Failed internationalization: The threat of accepting overseas sales one-sidedness}

Failed internationalization is defined both in terms of firm performance and significant retrenchment from exporting (invariably the only activity involved). This is linked to marketing inefficiencies resulting in stockpiles of unsold products. As Gareth (13 employees), the Medical Electronics Manufacturer understood only too well 'I don't like losing any order, I like to analyse every order I lose". Negative family-social-capital, in terms of ambition and sacrifices with a focus on the long term, combined with concentration of managerial power within a family business agenda can supply the feather that can turn the scales at the moment 
of disastrous family SME decision-making. Thus, it is the unchecked dominance of family upon the organizational-social-capital that produces negative internationalization outcomes. Jack (12 employees), reduced to tears describes his export failure "it just snowballed and we ended up being wholesalers rather than manufacturers". His story of export imbalance unfolds as follows:

\footnotetext{
"We wanted to use up the off cuts on the veneers to make chessboards. We bought out this client, a chessboards business, so we took on his commitments. Then it got so big that we were buying lots to do the chessboards but still ended up with the same off cuts we started off. Our American customers promised containers of orders but ended up with a little pallet. We built it up on a promise, employed extra 11 people and had probably the best product range. There's a hole and we were just throwing money in it. We had no time, just liquidator"
}

Timing lies behind such accounts of family SME export failure as cash flows can be severely affected by insufficient orders coming in. The managerial decisions in the aftermath of another family business's takeover by a PLC are also suggestive. The management structure has been transformed with the emergence of two directors and a definite splitting of responsibilities. The new MD supervises all of the work outside of the manufacturing site (sales team, newly appointed non-family manager and subcontracting), whilst the Operations Director deals with the joinery coordination on site. This has come about as a response to what became the downfall of an inexperienced son who "succeeded too early" and allowed the overheads/manufacturing costs to spiral out of control and a giant customer to monopolize the turnover. "No customers, no orders. Lack of sales was the problem ... Don't forget that all profits are gross, but all losses are net" (Sam, 60 employees, $1 \%$ exports).

Size notwithstanding, family SME export shrinkage rather than failure has been the effect of disturbing the firm's organizational-social-capital by rewarding the non-family manager with a major shareholding (1/3 partner) stake and thus depriving the family SME of strategic interest in employing a non-family manager who is suddenly perceived as an "expensive" investment to the board members: "I have a great belief in feeling the market. If it's Europe I tended to drive ... I would like to employ an export manager who could take over the travelling, but the exporting isn't great enough, so I have to do it myself as when I 
was an export manager, and I now do it from my desk ... We look upon our customers as a partnership ... the bottom line is how much money you make" (Harry, 16 employees, 10\% imports and $20 \%$ exports). It is only as long as non-family export managers remain the third party - rather than being integrated into a mutual identification family business agenda within the organization and are adequately rewarded, even up to the point of being given 'specialist' directorships, that exporting retains intensity. However, if the specialist director's role becomes 'mainstream', then their export directors' role stops being a proxy of their building cross-border agent trust and freedom from shared "bottom line" financial calculations (thus receding from a leading position). This is a harmful repercussion of achieving dominance in non-family ownership. In short, the export intensity of the family SME is not dependent on size, varies over historical time (with increasing, diminishing or no international market share), is shaped collectively and its organizational form matters.

\section{Discussion}

Case study data illustrate how leading internationalization (i.e. the attainment of success that stands the test of historical time) is linked with the achievement of a balance in the conflictual roles of family board members and non-family managers. This involves a separation of family SME ownership from internationalization management and thus delegation in the form of the employment of an outsider or a third party. In enterprises occupying this position the family SME owner(s) appear to assume only indirect control over internationalization and export managers are less captive to the inside management on account of asymmetrical risk considerations. To this extent, an 'altruistic family' composition of internationalization management personnel appears to decrease role specificity (a foundation of organizational-social-capital in Leana and Van Buren's view, 1999) and 
increase international risk exposure for family SMEs. On the basis of this finding we advance the following proposition:

Proposition 1: The management of internationalization by non-family managers (i.e. its separation from the owning family) is important in enhancing the ability of family SMEs to form networks with other businesses.

The evidence presented in our paper (for example among leading, and some opportunistic internationalization cases - such as Mark, James, and Harry's firms) also indicates that non-family managers, the so-called ambassadors to internationalization, are immune to family SME mutual identification influences (such as profit, control, costs and strategy) on the grounds of horizontal foreign contacts with corresponding level agents and other interpersonal competencies developed over their histories and across firms. The passage of historical time in non-family managers' various career paths allows them to avoid what is shown in the cases of Jack, Helen and Sam's firms to be a continuous and undifferentiated strategic focus (negative social capital) on the 'single generation' family SME internationalization. This organizational-social-capital explanation differs from optimistic views that 'family-social-capital' can potentially conquer all adversities and positively affect strategic adaptation in family firms (Salvato and Melin, 2008). Our cases suggest that it is not family (bonding), but organizational-social-capital (both bonding and bridging) that makes the important difference and such a distinction adds clarity to the study of international family business management. This argument directs attention to the different relationships of organizational actors to time (Sharma et al., 2014) and how the literature that has so far accepted the intentional continuity of past family SME internationalization strategies, sequentially maps international activity on time (that is "position-building process in a foreign market network", see Johanson and Vahlne, 2009: 1415) and therefore accepts "an ordered 
use of learning processes" (Bingham and Davis, 2012: 612), does not take into account erratic internationalization behaviour. On that basis we posit that:

Proposition 2: Non-family managers, and contacts acquired from previous employment and over their life course (i.e. in historical time), are important in generating organizational-social-capital, which (in turn) underpins international family SME resource management, upward-levelling norms and disordered learning processes.

Organizational-social-capital enables non-family managers to take both an ambassadorial role and other calculated risks in the foreign markets which are of benefit to the family business (already discussed in the previous Proposition): offering them a pathway to a shareholding position or 'specialist' directorship within the international family SME. However, when the pursuit of longevity entails the full integration of the non-family manager into the family SME (e.g. becoming a main partner), as shown in the case of Harry's firm, equal ownership dispersion leads to a loss of both independence in risk evaluation and organizational-social-capital. This results in receding exports over historical time. In this sense, as shown in the case of Lee's firm, even family members in transition can occasionally been seen to take on this third party role, albeit extra care is potentially needed in cases of creating a stewardship role vacancy within the organization (that is owner-managers singlehandedly driving the family firm's outward orientation without taking into account long-term profit considerations and leading to failure). To this extent, it is concluded here that successful international operations are a function of a balancing act between risk and the orientation of family business management, whilst the strategic behaviour of family SMEs can be linked to the varying risk profiles of insiders and thus be managed with intra-organizational arrangements. In this context, risk mirrors the aggregate balance coming out of varying the intensity of various family SME board members' managerial investment in shareholding but also historical time-related terms. Thus, our third proposition is: 
Proposition 3: Organizational-social-capital is of greater significance than familysocial-capital in positively affecting international family SME resource management.

Networks, knowledge and prior experience of non-family managers/directors have previously been considered by the proponents of the resource-based view of the firm (Sharma and Erramilli, 2004) as intangible resources that are exploited in order to obtain sustained competitive advantage in overseas markets and overcome the inability of family SMEs to form networks with other businesses (a direct effect of strong internal ties). In this study, however, we argue that it is not the presence or absence of international expertise and management capability that are typically seen to affect export success but rather their variable use (as shown particularly in the cases of Harry and Lee's firms where use changes as a result of radical repositioning within the organization) in the family SME intra-organizational context that is also history-dependent. The alleviation of resource constraints (size, orientation or family-related being the obvious ones, with networks as a major avenue for mitigating such constraints) has been the main thread for the reoccurring overlaps between the international SME and family business literature witnessed throughout this paper. Instead, this study challenges resourcefulness per se and puts the emphasis on the history of the international family SME and the reasons behind its varied resource management as the factors that determine ongoing export success.

\section{Conclusions}

\subsection{Concluding Remarks}

The East of England empirical material presented in our paper shows that successful family SME internationalization reflects intra-organizational conditions and in particular, the various ways in which the mutual influence of the life-courses of key family and non-family individuals involved in internationalization is managed over time. In this manner, actors are 
not seen as mere carriers of foreign market knowledge and international networks but rather their multiple individual histories obtain intra-organizational importance which succeeds in moving the debate beyond the revised Uppsala model where "actors are (only) implicitly present" as commitment decision-making resources (Johanson and Vahlne, 2009: 1423). We argue that the family SME internationalization focus on 'what' resources are needed to positively drive an incremental process such as "external ownership and influence via the board" (Pukall and Calabrò, 2014: 104) or "configurations of external resources" (Kraus et al., 2016) are, should not preclude research from 'how' resource management occurs in historical time. Our study helps especially to point out that increased international commitment for family SMEs is not only a reversible and non-deterministic process depending on existing performance and favourable prospects (according to the revised Uppsala model, ibid 2009), but also a coherently discontinuous one depending on the (future) pursuit of longevity and multiple actors' (past) histories. This aligns with Rosa et al.'s argument (2014: 375) that "low performance organizations can survive for a long time". In this context, we note that the heterogeneity of international family businesses is not only a matter of resources but also management processes. In this manner, we endorse a view of family SME internationalization as a historical process that holistically underpins combinations of conditions (if circumstances A, then international family SME position B) rather than a variance matter that measures the effects of isolated variables (more of $\mathrm{A}$ resources lead to more of B international family SME outcomes) (Welch et al., 2011; Bingham and Davis, 2012; Reuber, 2016).

We suggest that a distinction between historical and sequential time is particularly relevant for the family business context: where the pursuit of longevity means that international advances and reversals may take place within rather than between incremental stages. Within this context, change and learning may occur erratically and without causing 
international family SME progression across a sequence of incremental stages. Indeed, family SME internationalization often follows indirect pathways rooted in individual interactions whose 'microfoundations' we helped to elucidate by giving voice to family and non-family managers - a view that is currently missing from and could further enrich the international business literature (Gilgor et al., 2016).

Placed in the context of the portfolio entrpreneurship literature that first used the individual entrepreneur as the unit of analysis (Rosa et al., 2014), our research supports the view that it is not the single family firm but rather the individual interactions, of family and non-family managers, across firms that underpins the internationalization process. Here, we have shown in what ways the different position a family SME occupies is contingent on a combination of cross-border trust and family-SME board vision that affects how firms deal with the constraints of control, finance and market they experience. The latter circumstances, however, may not be stable over time (as shown in a number of cases examined in the paper).

Our findings identify a more complex set of reasons driving internationalization as a diversification activity: new opportunity (as identified by Rosa et al., 2014), as well as the attainment of cost advantages of scale that cannot be achieved solely through success in the domestic market (leading internationalization), and a more nuanced approach that stresses both endurance and the need for control (reluctant).

\subsection{Implications for Practice and Future Research}

The organizational-social-capital concept is of key importance for the practice of family SME internationalization. This is because, the suggestion of infusing organizationalsocial-capital into the management of internationalization can be easily implemented by family SMEs themselves through the employment of non-family managers, who possess contacts in previous employment (accumulated in historical time). Our findings also provide 
advice as to how the resource linked with non-family managers could be best utilised. Specifically, it is particularly important for successful family SME internationalization that non-family managers remain detached from ownership. This fits well with the pervasive demand of the owning family not to bring in additional majority shareholders and thus not to share strategic decision-making power. Internationalization (and the attainment of success) thus, does not have to negate the core values of family SME management but instead works best when it is treated as a well-balanced "part of the company's overall portfolio of activities" (Leonidou and Katsikeas, 1996: 525). However, as (stated previously) the internationalization circumstances of the firm may not be stable over time, family SME owner-managers should refrain from foreign position building strategies that do not take into account advancement without stage change as well as reversals. Instead, they should endeavour to vary their organizational-social-capital use as means of coping with turbulent environmental forces. Moreover, family SME owner-managers should scrutinize individual histories rather than learning sequences when they manage their business's portfolio of domestic and international activities.

We believe that the advancement of historical time for family-SME internationalization as a complement of sequential time offers scope for new and productive lines for future research. Of particular interest is research investigating the contingent conditions when discontinuities that also mark sequential time, accumulate in the context of historical time. Examples of these include: the separation of family SME ownership from internationalization management and thus delegation in the form of the employment of an non-family manager, and changes in family ownership and involvement (for example through succession or nepotistic hiring of family members) and their effect upon the internationalization position held by the firm. The adoption of a social capital view in family SME internationalization research also offers opportunities for new research. Of particular 
interest is the study of reversals in this process of creating organizational-social-capital (through the exit of non-family managers or tensions within family-social-capital) and their implication on the use of this resource and internationalization. This paper marginally engaged on the effects of negative social capital on family SME internationalization: we observe that this constitutes an often overlooked area that also merits investigation as well as consideration of its implications for practice.

\section{References}

Aaboen, L., Dubois, A. and Lind, F. (2012). Capturing processes in longitudinal multiple case studies. Industrial Marketing Management, 41(2): 235-246.

Abbott, A. (1991). History and Sociology: The Lost Synthesis. Social Science History, 15(2): 201-238.

Abbott, A. (1995). Sequence Analysis: New Methods for Old Ideas. Annual Review of Sociology, 21: 93-113.

Adler, P. S. and Kwon,S.-W. (2002). Social Capital: Prospects for a New Concept. Academy of Management Review, 27(1): 17-40.

Ahokangas, P. (1998). Internationalization and resources: an analysis of processes in Nordic SMEs, Doctoral Dissertation, Universitas Wasaensis, Vaasa.

Alvesson, M. and Sandberg, J. (2011). Generating research questions through problematization. Academy of Management Review, 36(2): 247-271.

Ancona, D.G., Okhuysen, G.A. and Perlow, L.A. (2001). Taking time to integrate temporal research. Academy of Management Review, 26(4): 512-529.

Arregle, J.-L., Hitt, M.A., Sirmon, D.G. and Very, P. (2007). The Development of Organizational-social-capital: Attributes of Family Firms. Journal of Management Studies, 44 (1): 73-95. 
Arregle, J.-L., Naldi, L., Nordqvist, M., and Hitt, M.A. (2012). Internationalization of familycontrolled firms: A study of the effects of external involvement in governance. Entrepreneurship Theory and Practice, 36(6): 1115-1143.

Ashforth, B.E., and Mael, F. (1989). Social Identity Theory and the Organization. Academy of Management Review, 14(1): 20-39.

Atherton, A. and Sear, L. (1998). Facing new (or no) frontiers? An examination of the new market development process in small businesses. $28^{\text {th }}$ European Small Business Seminar. Vienna: European-Foundation-for-Management-Development.

Bingham, C.B. and Davis, J.P. (2012). Learning sequences: their existence, effect, and evolution. Academy of Management Journal, 55(3): 611-641.

Brannen, J. and Nilsen, A. (2011). Comparative Biographies in Case-based Cross-national Research: Methodological Considerations. Sociology, 45(4): 603-618.

Bubolz, M. (2001). Family as source, user, and builder of social capital. Journal of SocioEconomics, 30(2): 129-131.

Carr, J.C., Cole, M.S., Ring, J.K. and Blettner, D.P. (2011). A measure of variations in internal social capital among family firms. Entrepreneurship Theory and Practice, 35(6): 1207-1227.

Cavusgil, T.S. (1980). The internationalization process of the firm, European Research, 8(6): 273-281.

Chenail, R.J. (2009). Communicating your qualitative research better. Family Business Review, 22(2): 105-108.

Chirico, F. and Salvato, C. (2008). Knowledge integration and dynamic organizational adaptation in family firms. Family Business Review, 21(2): 169-181.

Coleman, J.S. (1988) 'Social capital in the creation of human capital' American Journal of Sociology, 93: 291-321. 
Coviello, N.E. and Munro H.J. (1995). Growing the entrepreneurial firm. European Journal of Marketing, 29(7): 49-61.

Debrulle, J. and Maes, J. (2015). Start-ups' Internationalization: The Impact of Business Owners' Management Experience, Start-up Experience and Professional Network on Export Intensity. European Management Review 12(3), 171-187.

Doz, Y. (2011). Qualitative research for international business. Journal of International Business Studies, 42(5): 582-590.

Eisenhardt, K.M. (1989). Building Theories from Case Study Research. Academy of Management Review, 14(4): 532-550.

Fernández, Z. and Nieto, M. (2005). Internationalization Strategy of Small and Medium-Sized Family Businesses: Some Influential Factors. Family Business Review, 18(1): 77-89.

Fernández, Z. and Nieto, M. (2006). Impact of ownership on the international involvement of SMEs. Journal of International Business Studies, 37(3): 340-351.

Gallo, M.A. and Garcia-Pont, C. (1996). Important Factors in Family Business Internationalization. Family Business Review, 9(1): 45-59.

Gallo, M.A. and Sveen, J., (1991). Internationalizing the Family Business: Facilitating and Restraining Factors. Family Business Review, 4(2): 181-189.

Gligor, D.M., Esmark, C.L. and Gölgeci, I. (2016). Building international business theory: A grounded theory approach. Journal of International Business Studies, 47(1): 93-111.

Graebner, M.E., Martin, J.A. and Roundy, P.T. (2012). Qualitative data: Cooking without a recipe. Strategic Organization, 10(3): 276-284.

Graves, C. and Thomas, J. (2008) Determinants of the internationalization pathways of family firms: An examination of family influence. Family Business Review, 21(2): 151-167.

Hammersley, M. and Atkinson, P. (1983). Ethnography: Principles in Practice. London and New York: Routledge. 
Harris, S. and Wheeler, C. (2005). Entrepreneurs' relationships for internationalization: functions, origins and strategies. International Business Review, 14(2): 187-207.

Hassel, A., Höpner, M., Kurdelbusch, A. Rehder, B. and Zugehör, R. (2003). Two dimensions of the internationalization of firms. Journal of Management Studies, 40(3): 705-723.

Howorth, C., Rose, M., Hamilton, E. and Westhead, P. (2010). Family firm diversity and development: An Introduction. International Small Business Journal, 28(5): 437-451.

Johanson, J. and Mattsson, L.G. (1993). Internationalization in industrial systems - a network approach, strategies in global competition", in Buckley, P.J. and Ghauri, P.N. (Eds.). The Internationalization of the Firm: A Reader, Academic Press, London, pp. 303-22.

Johanson, J. and Vahlne, J.-E. (1977). The Internationalization process of the firm - a model of knowledge development and increasing foreign market commitments. Journal of International Business Studies, 8(1): 23-32.

Johanson, J. and Vahlne, J.-E. (2009). The Uppsala internationalization process model revisited: From liability of foreignness to liability of outsidership. Journal of International Business Studies, 40(9): 1411-1431.

Jones, M.V., Coviello, N., and Tang, Y.K. (2011). International entrepreneurship research (1989-2009): a domain ontology and thematic analysis, Journal of Business Venturing, 26(6): 284-303.

Julien, A.P., Joyal, A., Deschais, L., and Ramangalahy, C. (1997). A Typology of Strategic Behaviour among Small and Medium-Sized Exporting Businesses. A Case Study. International Small Business Journal, 15(2): 33-50.

Kalantaridis, C. (2004). Internationalization, Strategic Behaviour, and the Small Firm: A Comparative Investigation. Journal of Small Business Management, 42(3): 245-262.

Kontinen, T. and Ojala, A. (2010). The internationalization of family business strategy: A review of extant research. Journal of Family Business Strategy, 1(2): 97-107. 
Kontinen, T. and Ojala, A. (2011a). Network ties in the international opportunity recognition of family SMEs. International Business Review, 20(4): 440-453.

Kontinen, T. and Ojala, A. (2011b). International Opportunity Recognition among Small and Medium-Sized Family Firms. Journal of Small Business Management, 49(3): 490-514.

Kontinen, T. and Ojala, A. (2012) Internationalization pathways among family-owned SMEs. International Marketing Review, 29(5): 496-518.

Kotey, B. (2005). Goals, management practices, and performance of family SMEs. International Journal of Entrepreneurial Behaviour and Research, 11(1): 3-24.

Kraus, S. Mensching, H. Calabrò, A. Cheng, C.F. and Filser, M. (2016). Family firm internationalization: A configurational approach. Journal of Business Research, 69(11): 5473-5478.

Leana, C.R. and Van Buren, H.J. (1999). Organizational-social-capital and employment practices. Academy of Management Review, 24(3): 538-555.

Leonidou, L.C. and Katsikeas, C.S. (1996). The Export Development Process: An Integrative Review of Empirical Models. Journal of International Business Studies, 27(3): 517-551.

Leppäaho, T., Plakoyiannaki, E. and Dimitratos, P. (2016). The Case Study in Family Business: An Analysis of Current Research Practices and Recommendations. Family Business Review, 29(2): 159-173.

Liesch, P.W., Welch, L.S., Welch, D. McGaughey, S.L., Petersen, B., and Lamb, P. (2002). Evolving Strands of Research on Firm Internationalization. International Studies of Management and Organization, 32(1): 16-35.

Lubinski, C., Fear, J. and Pérez, P.F. (2013). Family Multinationals: Entrepreneurship, Governance and Pathways to Internationalization (Vol. 23). Routledge.

Millward, L.J. and Postmes, T. (2010). Who we are affects how we do: The financial benefits of organizational identification. British Journal of Management, 21(2): 327-339. 
Munn, N.D. (1992). The cultural anthropology of time: A cultural essay. Annual Review of Anthropology, 21(1): 93-123.

Nahapiet, J. and Ghoshal, S. (1998). Social Capital, Intellectual Capital, and the Organizational Advantage. Academy of Management Review, 23(2): 242-266.

Ng, W. and Roberts, J. (2007). Helping the family: the mediating role of outside directors in ethnic Chinese family firms. Human Relations, 60(2): 285-314.

Piercy, N. (1981). Company Internationalisation: Active and Reactive Exporting. European Journal of Marketing, 15(3): 26-40.

Payne, G.T., Moore, C.B., Griffis, S.E. and Autry, C.W. (2011). Multilevel challenges and opportunities in social capital research. Journal of Management, 37(2): 491-520.

Pearson, A.W. Carr, J.C. and Shaw, J.C. (2008) Towards a Theory of Familiness: A Social Capital Perspective. Entrepreneurship Theory and Practice, 32(6): 949-969.

Portes, A. (1998). Social Capital: Its Origins and Applications in Modern Sociology. Annual Review of Sociology, 24(1): 1-24.

Portes, A.. and Landolt, P (1996). The downside of social capital. The American Prospect, 26: $18-22$.

Pukall, T.J. and Calabrò, A. (2014). The Internationalization of Family Firms A Critical Review and Integrative Model. Family Business Review, 27(2): 103-125.

Reay, T. and Zhang, Z. (2014). Qualitative methods in family business research In: Melin, L., Nordqvist, M. and Sharma, P. (Eds.). (2014). The SAGE handbook of family business. Sage Publications.

Ricoeur, P. (1980). Narrative Time. Critical Inquiry, 7(1): 169-190.

Ryan, G.W. and Bernard, H.R. (2003). Techniques to identify themes. Field Methods, 15(1): 85-109. 
Reuber, A.R. (2016). An Assemblage-Theoretic Perspective on the Internationalization Processes of Family Firms. Entrepreneurship Theory and Practice, 40(6): 1269-1286.

Rosa, P., Howorth, C. and Discua Cruz, A. (2014). Habitual and portfolio entrepreneurship and the family in business. In: Melin, L., Nordqvist, M. and Sharma, P. (Eds.). (2014). The SAGE handbook of family business. Sage Publications.

Ruzzier, M. Hisrich, R. and Antoncic, B. (2006). SME Internationalization research: past, present and future. Journal of Small Business \& Enterprise Development 13(4): 476-97.

Salvato, C., and Melin, L. (2008). Creating Value Across Generations in Family-Controlled Businesses: The Role of Family Social Capital, Family Business Review, 21(3): 259276.

Sanchez-Famoso, V. Akhter, N. Iturralde, T. Chirico, F. and Maseda, A. (2015). Is non-family social capital also (or especially) important for family firm performance? Human Relations, 68(11): 1713-1743.

Scholes, L. Mustafa, M. and Chen, S. (2016). Internationalization of Small Family Firms: The Influence of Family from a Socioemotional Wealth Perspective. International Business Review, 58(2): 131-146.

Sciascia, S., and Mazzola, P. (2008). Family Involvement in Ownership and Management: Exploring Nonlinear Effects on Performance. Family Business Review, 21(4): 331-345.

Sciascia, S., Mazzola, P., Astrachan, J.H., and Pieper, T.M. (2013). Family Involvement in the Board of Directors: Effects on Sales Internationalization. Journal of Small Business Management, 51(1): 83-99.

Sharma, V.M., and Erramilli, M.K. (2004). Resource-based Explanation of Entry Mode Choice. Journal of Marketing Theory and Practice, 12(1): 1-18.

Sharma, P., Salvato, C. and Reay, T. (2014) Temporal Dimensions of Family Enterprise Research. Family Business Review, 27(1): 10-19. 
Shepherd, C. and Challenger, R. (2013). Revisiting paradigm (s) in management research: A rhetorical analysis of the paradigm wars. International Journal of Management Reviews, 15(2): 225-244.

Stake, R.E. (1994). Case Studies In: Denzin, N.K. and Lincoln, Y.S. (Eds.) Handbook of Qualitative Research. London: Sage Publications.

Tsang, E.W.K. (2002). Learning from overseas venturing experience: The case of Chinese family businesses. Journal of Business Venturing, 17(1): 21-40.

Yin, R.K. (2009). Case Study Research: Design and Methods. $4^{\text {th }}$ Edition; London: Sage.

Yu, T.F.-L. (2001). The Chinese family business as a strategic system: an evolutionary perspective. International Journal of Entrepreneurial Behaviour and Research, 7(1): $22-40$.

Uzzi, B. (1997). Social Structure and Competition in Interfirm Networks: The Paradox of Embeddedness. Administrative Science Quarterly, 42 (1): 35-67.

Welch, C. Piekkari, R. Plakoyiannaki, E. and Paavilainen-Mäntymäki, E. (2011). Theorising from case studies: Towards a pluralist future for international business research. Journal of International Business Studies, 42(5): 740-762.

Westhead, P. and Howorth, C. (2007). 'Types' of private family firms: an exploratory conceptual and empirical analysis. Entrepreneurship and Regional Development 19(5): $405-431$

Westlund, H. and Bolton, R. (2003) 'Local social capital and entrepreneurship' Small Business Economics, 21(2): 77-113.

Zahra, S.A. (2003). International expansion of U.S. manufacturing family businesses: the effect of ownership and involvement. Journal of Business Venturing, 18(4): 495-512.

Zahra, S.A., Ucbasaran, D. and Newey, L.R. (2009). Social knowledge and SMEs' innovative gains from internationalization. European Management Review 6(2): 81-93. 
Table 1: Overview of the Cases

\begin{tabular}{|c|c|c|c|c|c|c|c|c|c|c|c|c|c|}
\hline FIRMS & Mark & Gareth & Lee & Jack & James & Peter & Alice & Nick & Harry & Helen & Jim & Lucy & Sam \\
\hline \multicolumn{14}{|c|}{ Firm Characteristics } \\
\hline $\begin{array}{l}\text { Manufacturing } \\
\text { Industry }\end{array}$ & $\begin{array}{l}\text { Outdoor } \\
\text { Lighting } \\
\text { equipment }\end{array}$ & $\begin{array}{l}\text { Medical } \\
\text { power } \\
\text { suppliers }\end{array}$ & $\begin{array}{l}\text { Fishing } \\
\text { equipment }\end{array}$ & $\begin{array}{l}\text { Veneer } \\
\text { panel } \\
\text { speciali } \\
\text { st }\end{array}$ & $\begin{array}{l}\text { Plastic } \\
\text { packaging } \\
\text { material }\end{array}$ & $\begin{array}{l}\text { Panel } \\
\text { Builder }\end{array}$ & $\begin{array}{l}\text { Motor Sport } \\
\text { performance } \\
\text { car } \\
\text { suspension }\end{array}$ & $\begin{array}{l}\text { Cereal } \\
\text { Industry } \\
\text { Elevators }\end{array}$ & $\begin{array}{l}\text { Food } \\
\text { cutting } \\
\text { surfaces }\end{array}$ & $\begin{array}{l}\text { Publi- } \\
\text { shing }\end{array}$ & $\begin{array}{l}\text { Electroni } \\
\text { c security } \\
\text { systems }\end{array}$ & $\begin{array}{l}\text { Printing } \\
\text { /propert } \\
\text { y firm }\end{array}$ & Shop fitting \\
\hline Location & $\begin{array}{l}\text { Hertfords } \\
\text { hire }\end{array}$ & $\begin{array}{l}\text { Bedfordsh } \\
\text { ire }\end{array}$ & Essex & $\begin{array}{l}\text { Hertfor } \\
\text { dshire }\end{array}$ & Essex & Bed/shire & Essex & Essex & Essex & $\begin{array}{l}\text { Hertfor } \\
\text { dshire }\end{array}$ & Essex & $\begin{array}{l}\text { Hertfor } \\
\text { dshire }\end{array}$ & $\begin{array}{l}\text { Hertfordshi } \\
\text { re }\end{array}$ \\
\hline Age of FB* & 79 & 28 & 29 & 49 & 40 & 14 & 25 & 54 & 122 & 15 & 28 & 40 & 36 \\
\hline FB Generation & $2^{\text {nd }}$ & $1^{\text {st }}$ & $1^{\text {st }}$ & $2^{\text {nd }}$ & $2^{\text {nd }}$ & $1^{\text {st }}$ & $2^{\text {nd }}$ & $1^{\mathrm{st}}$ & $4^{\text {th }}$ & $1^{\text {st }}$ & $1^{\mathrm{st}}$ & $1^{\text {st }}$ & $2^{\text {nd }}$ \\
\hline $\begin{array}{l}\text { \% Family Share } \\
\text { Ownership }\end{array}$ & $100 \%$ & $100 \%$ & $100 \%$ & $100 \%$ & $100 \%$ & $100 \%$ & $100 \%$ & $\mathrm{MBO} * *$ & $34 \%$ & $100 \%$ & $80 \%$ & $100 \%$ & FTO† \\
\hline Employees (no) & 160 & 13 & 55 & 12 & 88 & $\begin{array}{l}16 \\
\text { Internatioı }\end{array}$ & $\begin{array}{l}19 \\
\text { lization }\end{array}$ & 120 & 16 & 7 & 20 & 5 & 60 \\
\hline \% Imports & $5 \%$ & $20 \%$ & $95 \%$ & N/A & N/A & N/A & $60 \%$ & N/A & $10 \%$ & N/A & $8 \%$ & N/A & N/A \\
\hline \% Exports & $25 \%$ & $5 \%$ & $40 \%$ & $0 \%$ & $40 \%$ & $7 \%$ & $25 \%$ & $2 \%$ & $20 \%$ & $40 \%$ & $1 \%$ & $3 \%$ & $1 \%$ \\
\hline $\begin{array}{l}\text { International } \\
\text { Production }\end{array}$ & $\begin{array}{l}\text { Yes } \\
\text { (China) }\end{array}$ & No & No & No & $\begin{array}{l}\text { Yes } \\
\text { (USA) }\end{array}$ & No & No & No & No & No & No & No & No \\
\hline Foreign & 3 & 1 & 25 & 2 & 10 & 2 & 40 & 5 & 16 & 12 & 4 & 1 & 3 \\
\hline markets & $\begin{array}{l}\text { EU·Emirat } \\
\text { es }\end{array}$ & USA & $\begin{array}{l}\text { Worldwid } \\
\mathrm{e}\end{array}$ & $\begin{array}{l}\text { EU.US } \\
\text { A }\end{array}$ & $\begin{array}{l}\text { Worldwid } \\
\mathrm{e}\end{array}$ & EU & Worldwide & Worldwide & $\begin{array}{l}\text { Worldwi } \\
\text { de }\end{array}$ & West & $\begin{array}{l}\text { EU·Bahra } \\
\text { in }\end{array}$ & $\begin{array}{l}\text { Gibralta } \\
\mathrm{r}\end{array}$ & EU \\
\hline Direct Exports & No & No & No & No & No & No & Yes & No & No & No & Yes & Yes & Yes \\
\hline \multicolumn{14}{|c|}{ Internationalization Position } \\
\hline $\begin{array}{l}\text { Cross-border } \\
\text { Trust }\end{array}$ & $\begin{array}{l}\text { Yes, } \\
\text { export } \\
\text { manager } \\
\text { cross- } \\
\text { border } \\
\text { trust }\end{array}$ & No & $\begin{array}{l}\text { Yes, } \\
\text { owner } \\
\text { cross- } \\
\text { border } \\
\text { trust }\end{array}$ & No & $\begin{array}{l}\text { Yes, } \\
\text { export } \\
\text { manager } \\
\text { cross- } \\
\text { border } \\
\text { trust }\end{array}$ & No & No & No & $\begin{array}{l}\text { Yes, } \\
\text { owner } \\
\text { cross- } \\
\text { border } \\
\text { trust }\end{array}$ & $\begin{array}{l}\text { Yes, } \\
\text { owner } \\
\text { cross- } \\
\text { border } \\
\text { trust }\end{array}$ & $\begin{array}{l}\text { Yes, } \\
\text { extension } \\
\text { of } \\
\text { domestic } \\
\text { customer } \\
\text { s }\end{array}$ & No & No \\
\hline \multirow{3}{*}{$\begin{array}{l}\text { SME Board } \\
\text { Composition } \\
\text { Specialist } \\
\text { director }\end{array}$} & Diverse & $\begin{array}{l}\text { Non- } \\
\text { diverse }\end{array}$ & Diverse & $\begin{array}{l}\text { Non- } \\
\text { diverse }\end{array}$ & Diverse & $\begin{array}{l}\text { Non- } \\
\text { diverse }\end{array}$ & Non-diverse & Diverse & Diverse & Diverse & Diverse & $\begin{array}{l}\text { Non- } \\
\text { diverse }\end{array}$ & $\begin{array}{l}\text { Non- } \\
\text { diverse }\end{array}$ \\
\hline & $\begin{array}{l}\text { Yes, hired } \\
\text { specificall }\end{array}$ & No & $\begin{array}{l}\text { Yes, but } \\
\text { new role }\end{array}$ & No & $\begin{array}{l}\text { Yes, hired } \\
\text { specificall }\end{array}$ & No & No & $\begin{array}{l}\text { Yes, hired } \\
\text { specifically }\end{array}$ & $\begin{array}{l}\text { Yes, } \\
\text { hired }\end{array}$ & No & Yes & No & Yes \\
\hline & $\mathrm{y}$ for & & filled by & & $\mathrm{y}$ for & & & for exports. & specifical & & & & \\
\hline
\end{tabular}




\begin{tabular}{|c|c|c|c|c|c|c|c|c|c|c|c|c|c|}
\hline \multirow{5}{*}{ Position } & \multicolumn{2}{|l|}{ exports } & \multicolumn{2}{|l|}{ the owner } & \multicolumn{3}{|l|}{ exports } & Not replaced & \multicolumn{2}{|l|}{ ly for } & \multirow{5}{*}{$\begin{array}{l}\text { Opportun } \\
\text { istic } \\
\text { Exporter }\end{array}$} & \multirow{5}{*}{$\begin{array}{l}\text { Relucta } \\
\text { nt } \\
\text { Exporte } \\
\mathrm{r}\end{array}$} & \multirow{5}{*}{$\begin{array}{l}\text { Failed } \\
\text { Exporter }\end{array}$} \\
\hline & \multirow{4}{*}{$\begin{array}{l}\text { Leading } \\
\text { Exporter }\end{array}$} & \multirow{4}{*}{$\begin{array}{l}\text { Reluctant } \\
\text { Exporter }\end{array}$} & \multirow{4}{*}{$\begin{array}{l}\text { Leading } \\
\text { Exporter }\end{array}$} & \multirow{4}{*}{$\begin{array}{l}\text { Failed } \\
\text { Exporte } \\
\mathrm{r}\end{array}$} & \multirow{5}{*}{$\begin{array}{l}\text { Leading } \\
\text { Exporter }\end{array}$} & \multirow{4}{*}{$\begin{array}{l}\text { Reluctant } \\
\text { Exporter }\end{array}$} & \multirow{4}{*}{$\begin{array}{l}\text { Reluctant } \\
\text { Exporter }\end{array}$} & \multirow{4}{*}{$\begin{array}{l}\text { when left } \\
\text { after } 10 \\
\text { years' } \\
\text { service } \\
\text { Opportunisti } \\
\text { c Exporter }\end{array}$} & \multirow{4}{*}{$\begin{array}{l}\text { exports. } \\
\text { Elevated } \\
\text { into } \\
\text { ownershi } \\
\text { p role. } \\
\text { Opportun } \\
\text { istic } \\
\text { Exporter }\end{array}$} & \multirow{4}{*}{$\begin{array}{l}\text { Opp } \\
\text { Exprtr }\end{array}$} & & & \\
\hline & & & & & & & & & & & & & \\
\hline & & & & & & & & & & & & & \\
\hline & & & & & & & & & & & & & \\
\hline \multicolumn{13}{|c|}{ Interviewee characteristics } & \\
\hline Position within & Export & Joint & Warehous & Chairm & Export & Owner & Sales/Marke & Sales & Partner & Sales & Sales & Owners & Operations \\
\hline FB & Director & $\begin{array}{l}\text { owner \& } \\
\text { MD }\end{array}$ & e Manager & an & Manager & and MD & ting Director & Engineer & and MD & staff & Manager & $\&$ MDs & Director \\
\hline $\begin{array}{l}\text { Duration of FB } \\
\text { Relationship }\end{array}$ & $\begin{array}{l}25 \\
\text { (years) }\end{array}$ & $\begin{array}{l}28 \\
\text { (years) }\end{array}$ & $\begin{array}{l}4 \\
\text { (years) }\end{array}$ & $\begin{array}{l}33 \\
\text { (years) }\end{array}$ & $\begin{array}{l}9 \\
\text { (years) }\end{array}$ & $\begin{array}{l}5 \\
\text { (years) }\end{array}$ & $\begin{array}{l}4 \\
\text { (years) }\end{array}$ & $\begin{array}{l}20 \\
\text { (years) }\end{array}$ & $\begin{array}{l}30 \\
\text { (years) }\end{array}$ & $\begin{array}{l}11 \\
\text { (years) }\end{array}$ & $\begin{array}{l}5 \\
\text { (years) }\end{array}$ & $\begin{array}{l}40 \\
\text { (years) }\end{array}$ & $\begin{array}{l}8 \\
\text { (years) }\end{array}$ \\
\hline
\end{tabular}

* FB: Family Business

× MD: Managing Director ** MBO: Management Buyout

$\dagger$ FTO: Firm Taken Over 
Figure 1. The Conceptual Framework

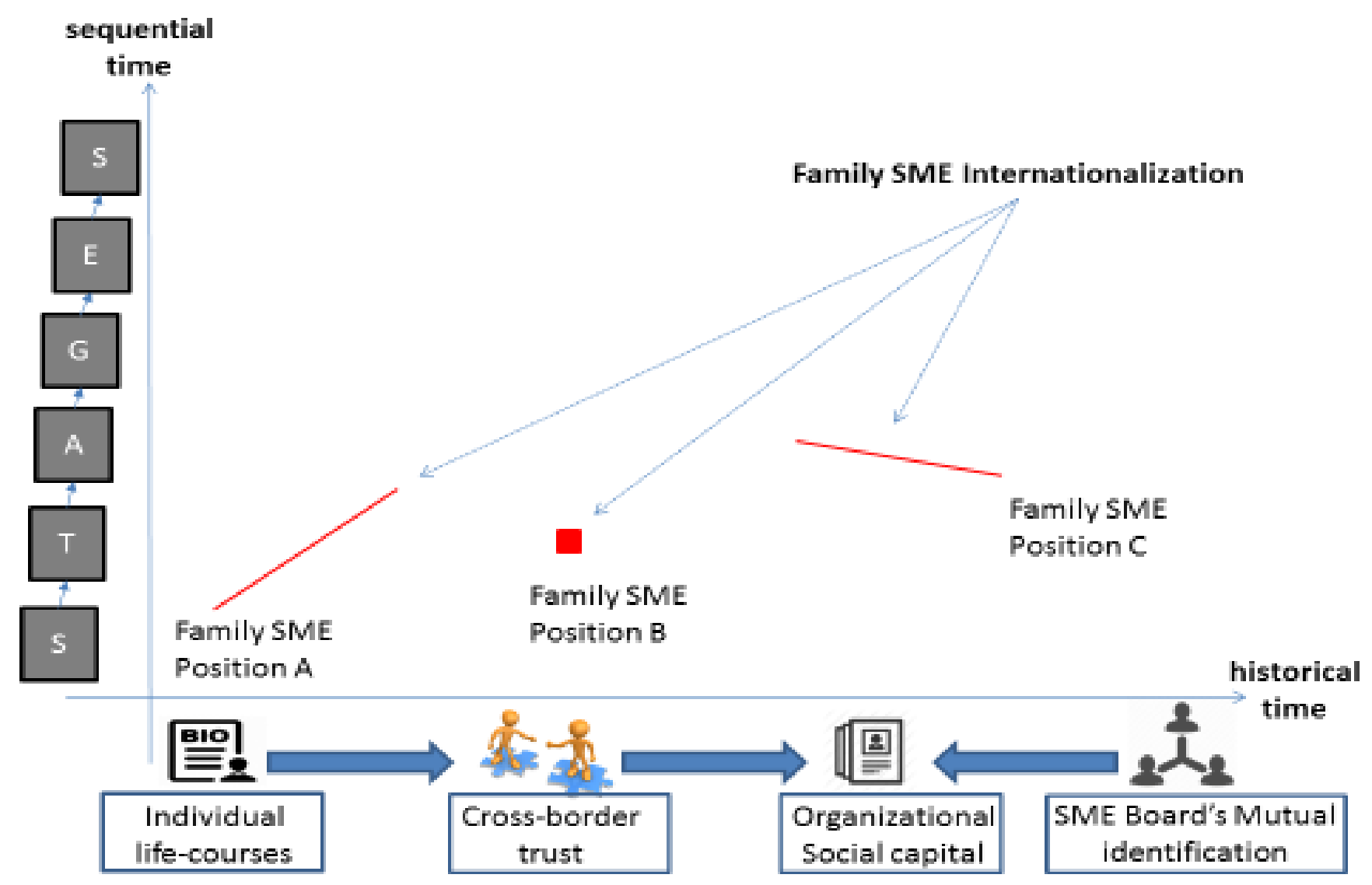


Figure 2. Successful Internationalization for Family SMEs: Is it gradual, personalized or a risk balancing act?

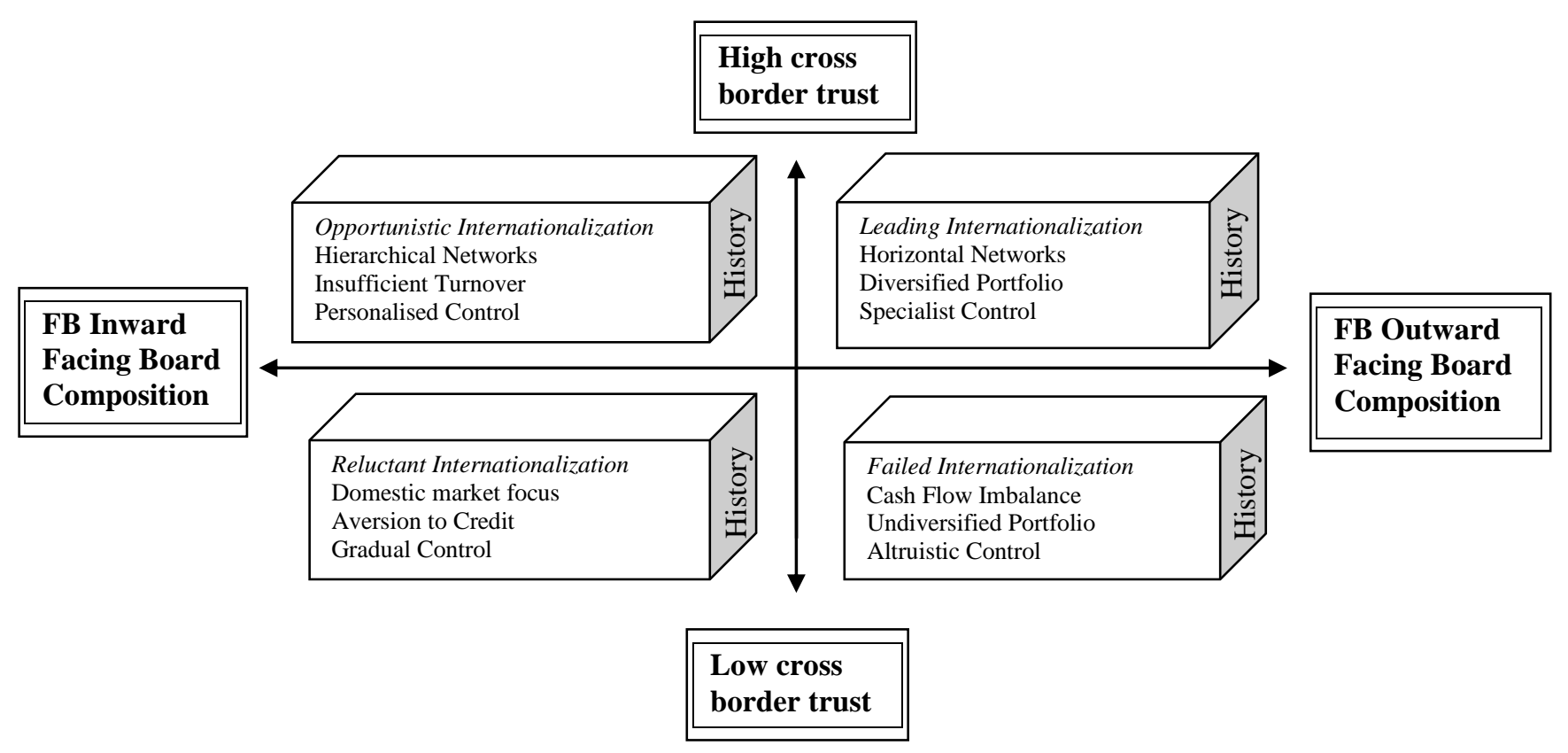

